\title{
Peningkatan Quality Ownership Untuk Menjaga Kualitas Produk Di PT. XYZ Dengan Metode Continuous Improvement
}

\author{
Syahgita Soma Hidayat $^{{ }^{*}}$, Fourry Handoko ${ }^{2}$, Dimas Indra Laksmana ${ }^{3}$ \\ ${ }^{1}$ Produksi Cigarillo, Other Tobacco Product Plant, PT. Sampoerna Indonesia Sembilan \\ ${ }^{2,3}$ Teknik Industri, Institut Teknologi Nasional Malang \\ "E-mail: agit.hidayat@gmail.com
}

\begin{abstract}
Abstrak
Dalam proses perbaikan terus menerus peran dari sumber daya manusia sangatlah penting, setiap individu/karyawan harus menyadari pentingnya kualitas produk, sehingga setiap karyawan tersebut harus mempunyai rasa kepemilikan terhadap kualitas (Quality Ownership). Terkait Quality Ownership tersebut, pengukuran terhadap nilai dari Visual Quality Index (VQI) digunakan sebagai peringatan bagi perusahaan untuk melakukan evaluasi terhadap kualitas baik proses maupun produk. Pada penelitian peningkatan ini Quality Ownership diukur dengan metode Continuous Improvement (PDCA) melalui VQI yang terintegrasi dalam metode A3 Problem Solving dan Failure Mode and Effects Analysis (FMEA), tahap pertama adalah melakukan brainstorming dengan beberapa orang yang berperan dalam proses produksi dengan metode 5 why yang disusun dalam tree diagram analysis untuk mencari akar permasalahan, dilanjutkan dengan penggunaan tabel FMEA untuk mendapatkan nilai dari Risk Potensial Number (RPN), setelah mengetahui nilai dari RPN kemudian adalah membuat countermeasure dari permasalahan dan membuat jadwal perbaikan, tahap selanjutnya adalah menerapkan dan memonitoring proses dengan cara melakukan pengamatan menggunakan nilai dari VQI. Peningkatan Quality Ownership dapat dilihat dari perubahan nilai VQI yang semula di atas 200 dari rata-rata turun menjadi 193 dan konsisten di bawah angka 200, hal tersebut menunjukkan bahwa terjadi pengendalian kualitas dalam proses produksi dengan kata lain adalah terjadi peningkatan Quality Ownership dalam perilaku karyawan dalam bekerja.
\end{abstract}

Kata Kunci : Continuous Improvement, kualitas, Quality Ownership,

\section{Pendahuluan}

PT. XYZ adalah sebuah perusahaan rokok dengan pangsa pasar internasional, perusahaan ini merupakan anak perusahaan dari perusahaan multi internasional yang berada di Indonesia, PT. XYZ berfokus pada 3 produk yaitu sigaret kretek (mesin), Other Tobacco Product (OTP) dengan ciri khas adanya penambahan daun tembakau (leaf) yang digulung pada rokok, sehingga rokok tersebut menyerupai cerutu (cigarillos) dan juga tembakau murni dalam kemasan (Roll Your Own) yang nantinya kesemua produk tersebut akan diekspor ke Eropa. Quality ownership adalah rasa kepemilikan terhadap kualitas, hal ini merupakan tanggung jawab semua individu yang berada di area produksi untuk selalu memastikan semua produk yang dihasilkan sesuai dengan standar yang telah ditetapkan oleh perusahaan, menumbuhkan Quality Ownership tentunya harus menumbuhkan sense of belonging atau rasa memiliki suatu kelompok atau organisasi (perusahaan). Sense of belonging tersebut merupakan ekspresi jiwa yang penting dalam kehidupan pekerja akan tanggung-jawab terhadap perusahaan. Rasa memiliki juga akan berdampak secara signifikan di dalam perilaku seseorang. Seseorang yang memiliki rasa memiliki akan bertindak peduli, terikat, memiliki empati, termotivasi bahkan mampu memberdayakan dirinya sendiri meskipun tidak ada stimulan [1]. Dalam temuan awal penelitian ini, kurangnya Quality Ownership pada PT. XYZ ditunjukkan dengan tingginya nilai dari Visual Quality Index (VQI) dengan rata-rata 200, beberapa faktor penyebabnya adalah teridentifikasi sebagai akibat kurangnya kesadaran untuk melakukan Inspection Proses Control (IPC) sehingga 
menyebabkan keterlambatan dalam memperbaiki suatu defect dan juga penilaian yang dilakukan untuk Feedback for Operation (FTO) bersifat subyektif dan kurang transparan sehingga karyawan tidak mengetahui pencapaian penilaian tahunannya yang menyebabkan kurangnya motivasi karyawan untuk ikut berpartisipasai dalam menjaga standar kualitas yang telah ditentukan oleh perusahaan. Aspek dalam penentuan nilai dari FTO yang tidak transparan juga mengakibatkan kesalahan orientasi dalam bekerja. Pada saat itu aspek penilaian dengan bobot persentase paling tinggi yang diketahui oleh karyawan adalah uptime mesin sehingga yang menjadi prioritas utama adalah meningkatkan produktivitas dan bukanlah menjaga kualitas. Peningkatan dan pengendalian kualitas produksi memerlukan komitmen untuk perbaikan yang melibatkan antara faktor manusia (motivasi) dan faktor mesin seperti dijelaskan dalam teknologi Pengendalian Mutu Terpadu (Total Quality Control) sebagai pendekatan manajemen modern, adalah suatu pendekatan dalam menjalankan suatu usaha untuk memaksimumkan daya saing perusahaan melalui perbaikan secara terus-menerus (continous improvement) [2].

Dalam proses produksi yang telah dilaksanakan perusahaan, kadangkala terjadi hambatanhambatan yang menyebabkan kerusakan atau penyimpangan-penyimpangan pada produk yang dihasilkan sehingga produk tersebut tidak dapat dijual atau dipasarkan ke customer [3]. Dari permasalahan di atas maka perusahaan perlu mengadakan evaluasi terhadap proses yang berlangsung selama ini. Penyimpangan-penyimpangan pada produk tentu saja bisa dikurangi jika adanya support dari karyawan. Salah satu bentuk support karyawan terhadap kualitas adalah dengan cara mengubah budaya dan perilaku karyawan dalam bekerja dengan cara transfer knowledge terkait dengan pentingnya kualitas produk [4]. Dalam penelitian ini obyek yang akan diamati adalah karyawan, dengan asumsi mesin yang digunakan dalam keadaan baik, material yang digunakan dalam kondisi baik sehingga fokus penelitian adalah tertuju pada karyawan sebagai peranan penting dalam proses produksi, hal ini dilakukan untuk meningkatkan Quality Ownership pada karyawan. Sebagai langkah awal untuk menjaga kualitas produk adalah dengan pendekatan metode Continuous Improvement, langkahlangkahnya adalah dengan menggunakan Plan, Do, Check and Act (PDCA) yang terintegrasi pada metode A3 Problem Solving dengan analisis menggunakan pendekatan metode failure mode and effect analisis

\section{Metode Penelitian}

Langkah pertama adalah melakukan pengamatan di lapangan dalam kegiatan proses produksi dan menentukan kasus yang akan dibahas dalam penelitian ini. Peneliti juga melakukan studi pendahuluan, yaitu dengan cara meneliti tentang apa saja yang mempengaruhi ketidaksesuaian yang terjadi di dalam prosses produksi, hal ini juga diimbangi dengan studi literatur yaitu dengan cara mencari jurnal tentang apa yang akan peneliti bahas dalam penelitian sebagai bentuk identifikasi masalah. Perumusan masalah ditentukan setelah melalui telaah terhadap permasalahan dilapangan dan dikaitkan dengan ketidak tersediaan penelitian sejenis dengan me-review beberapa penelitian terdahulu serta jurnal-jurnal yang relevan sebagai referensi dalam perumusan masalah. Selanjutnya, tujuan penelitian ini ditentukan yaitu; peningkatan kualitas produk dengan cara meningkatkan rasa kepemilikan terhadap kualitas (Quality Ownership) dan monitoring evaluasi hasil dari implementasi penelitian.

Selanjutnya dilakukan pengumpulan dan pengolahan data. Penelitian ini menggunakan konsep continuous improvement yang diterapkan dalam bentuk metode A3 Problem Solving. Pada konsep continuous improvement atau perbaikan berkelanjutan diterapkan dengan menggunakan Plan-DoCheck-Action. Plan dalam metode A3 Problem Solving akan dilakukan Clarify the problem yang akan disajikan dalam background, breakdown the problem dalam Curent Condition kemudian adalah menentukan target dari pemecahan masalah, tahap terakhir dari plan dalam A3 problem solving adalah Analyze untuk mendapatkan root cause the problem. Do dalam A3 problem solving akan membuat countermeasure dari root cause yang didapatkan dari tahap analyze. Check dalam A3 Problem Solving akan dilakukan Pembuatan jadwal pelaksanaan dan juga jadwal monitoring. Sedangkan action dalam A3 Problem Solving akan dilakukan dengan Follow up dari setiap countermeasure yang sudah dijadwalkan sebelumnya. Setelah dilakukan tahap pengumpulan dan pengolahan data kemudian dilakukan perbandingan sebelum dan sesudah usulan perbaikan berkelanjutan. Selanjutnya dilakukan 
penarikan kesimpulan dimana akan menjawab tujuan penelitian. Pada langkah terakhir diberikan juga rekomendasi saran untuk perbaikan, kelemahan penelitian, serta peluang penelitian selanjutnya

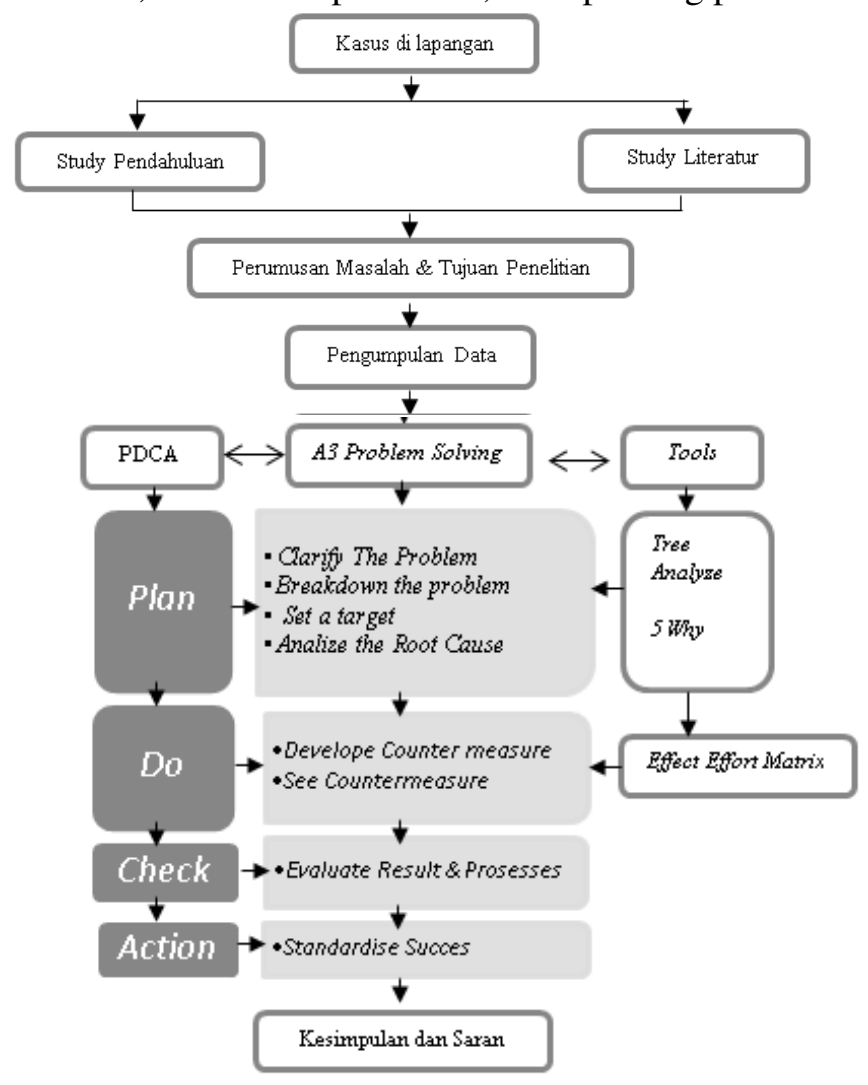

Gambar 1. Diagram Alir Penelitian

\section{Hasil Penelitian}

Berikut tabel hasil FMEA dari akar masalah setelah melakukan brainstorming untuk mendapatkan beberapa faktor dalam proses produksi yang mempengaruhi kurangnya Quality Ownership dan juga kurangnya motivasi karyawan untuk Quality Ownership

Tabel 1 Hasil Pengolahan Root Cause Dalam FMEA

\begin{tabular}{|c|c|c|c|c|c|c|c|c|}
\hline $\begin{array}{l}\text { Item / } \\
\text { Function }\end{array}$ & $\begin{array}{l}\text { Potential } \quad \text { Failure } \\
\operatorname{Mode}(s)\end{array}$ & $\begin{array}{l}\text { Potential Effect(s) } \\
\text { of Failure }\end{array}$ & $\begin{array}{l}\text { Se } \\
\text { ver } \\
i y\end{array}$ & $\begin{array}{l}\text { Potential Cause }(\text { s)/ } \\
\text { Mechanism(s) of Failure }\end{array}$ & $\begin{array}{l}\text { Oc } \\
\mathrm{cu} \\
\mathrm{ra} \\
\mathrm{nt}\end{array}$ & $\begin{array}{l}\text { Current Design } \\
\text { Controls }\end{array}$ & $\begin{array}{l}\text { De } \\
\text { tec } \\
\text { tio } \\
n\end{array}$ & $R P N$ \\
\hline $\begin{array}{l}\text { Penilaian } \\
\text { Individu }\end{array}$ & $\begin{array}{l}\text { Tidak ada penilaian } \\
\text { sampai individu }\end{array}$ & $\begin{array}{l}\text { Tidak mengetahui } \\
\text { hasil pencapaian }\end{array}$ & 6 & $\begin{array}{l}\text { Kurangnya kepedulian } \\
\text { karyawan }\end{array}$ & 7 & Inspeksi & 5 & 210 \\
\hline $\begin{array}{l}\text { Pembobotan nilai } \\
\text { karyawan }\end{array}$ & $\begin{array}{l}\text { Tidak ada } \\
\text { pembobotan nilai } \\
\text { karyawan }\end{array}$ & $\begin{array}{l}\text { Leader menilai } \\
\text { intuisi dan attitude }\end{array}$ & 6 & $\begin{array}{l}\text { Kurangnya kepedulian } \\
\text { karyawan }\end{array}$ & 5 & Membuat & 4 & 120 \\
\hline $\begin{array}{l}\text { Form monitoring } \\
\text { performa individu }\end{array}$ & $\begin{array}{l}\text { Tidak ada alat bantu } \\
\text { monitoring performa } \\
\text { tiap individu dan } \\
\text { mesin }\end{array}$ & $\begin{array}{l}\text { Tidak mengetahui } \\
\text { pencapaian individu }\end{array}$ & 5 & $\begin{array}{l}\text { Kurangnya kepedulian } \\
\text { karyawan }\end{array}$ & 5 & $\begin{array}{l}\text { Membuat form } \\
\text { performa } \\
\text { individu }\end{array}$ & 3 & 75 \\
\hline $\begin{array}{l}\text { Metode } \\
\text { pengecekan }\end{array}$ & $\begin{array}{l}\text { Pengecekan hanya } \\
\text { di lakukan operator }\end{array}$ & $\begin{array}{l}\text { Tidak ada jobdesk } \\
\text { pengecekan untuk } \\
\text { helper }\end{array}$ & 7 & $\begin{array}{l}\text { Sering di temukan NC } \\
\text { yang sama dan berulan }\end{array}$ & 6 & Inspeksi & 5 & 210 \\
\hline $\begin{array}{l}\text { Form monitoring } \\
\text { downtime }\end{array}$ & $\begin{array}{l}\text { Belum ada lembar } \\
\text { monitoring } \\
\text { downtime mesin } \\
\end{array}$ & $\begin{array}{l}\text { Tidak tersampaikan } \\
\text { informasi }\end{array}$ & 6 & $\begin{array}{l}\text { Sering di temukan NC } \\
\text { yang sama dan berulan }\end{array}$ & 6 & $\begin{array}{l}\text { Membuat form } \\
\text { monitoring } \\
\text { downtime }\end{array}$ & 4 & 144 \\
\hline $\begin{array}{l}\text { One point lesson } \\
\text { perbaikan defect }\end{array}$ & $\begin{array}{l}\text { belum ada OPL } \\
\text { dalam perbaikan } \\
\text { defect }\end{array}$ & $\begin{array}{l}\text { Perbaikan tidak } \\
\text { selaras }\end{array}$ & 7 & $\begin{array}{l}\text { Sering di temukan NC } \\
\text { yang sama dan berulan }\end{array}$ & 7 & Membuat OPL & 5 & 245 \\
\hline
\end{tabular}


Setelah melakukan root cause analisis dan juga melakukan pendekatan dengan menggunakan metode FMEA dari pokok permasalahan yang ada maka tahap selanjutnya adalah membuat countermeasure plan atau rencana penanganan berdasarkan nilai RPN, countermeasure dengan nilai RPN tinggi menjadi prioritas penanganan untuk dilakukan terlebih dahulu, countermeasure plan dapat dilihat pada tabel 2 di bawah ini:

Tabel 2. Countermeasure Plan

\begin{tabular}{|l|l|l|}
\hline No & Problem & Counter measure \\
\hline 1 & $\begin{array}{l}\text { Belum ada One Point Lesson (OPL) } \\
\text { Untuk perbaikan suatu defect }\end{array}$ & $\begin{array}{l}\text { Membuat OPL untuk menyelaraskan antar operator dalam } \\
\text { memperbaiki suatu defect }\end{array}$ \\
\hline 2 & $\begin{array}{l}\text { Belum ada jobdesk pengecekanrutin } \\
\text { buat helper }\end{array}$ & $\begin{array}{l}\text { Menambahkan job desk pengecekan rutin (IPC) untuk helper } \\
\text { dan juga mensosialisasikannya }\end{array}$ \\
\hline 3 & $\begin{array}{l}\text { Belum ada penilaian } \\
\text { Sampai individu }\end{array}$ & $\begin{array}{l}\text { Membuat breakdown penilaian detail masing-masing } \\
\text { karyawan sesuai dengan area pekerjaannya. }\end{array}$ \\
\hline 4 & $\begin{array}{l}\text { Belum ada alat bantu } \\
\text { Monitoring performance } \\
\text { Tiap individu dan mesin }\end{array}$ & $\begin{array}{l}\text { Membuat alat bantu untuk monitoring performance untuk } \\
\text { karyawan sesuai dengan area proses / mesin }\end{array}$ \\
\hline 2 & $\begin{array}{l}\text { Tidak ada pembobotan nilai } \\
\text { Individu karyawan }\end{array}$ & $\begin{array}{l}\text { Membuat skala pembobotan untuk masing-masing aspek yang } \\
\text { di nilai }\end{array}$ \\
\hline 5 & $\begin{array}{l}\text { Belum ada lembar monitoring } \\
\text { downtime mesin }\end{array}$ & $\begin{array}{l}\text { Membuat lembar monitoring downtime sebagai media } \\
\text { komunikasi antar shift terhadap problem mesin yang terkini }\end{array}$ \\
\hline
\end{tabular}

Beberapa follow up dari countermeasure plan dapat dilihat pada gambar di bawah ini:
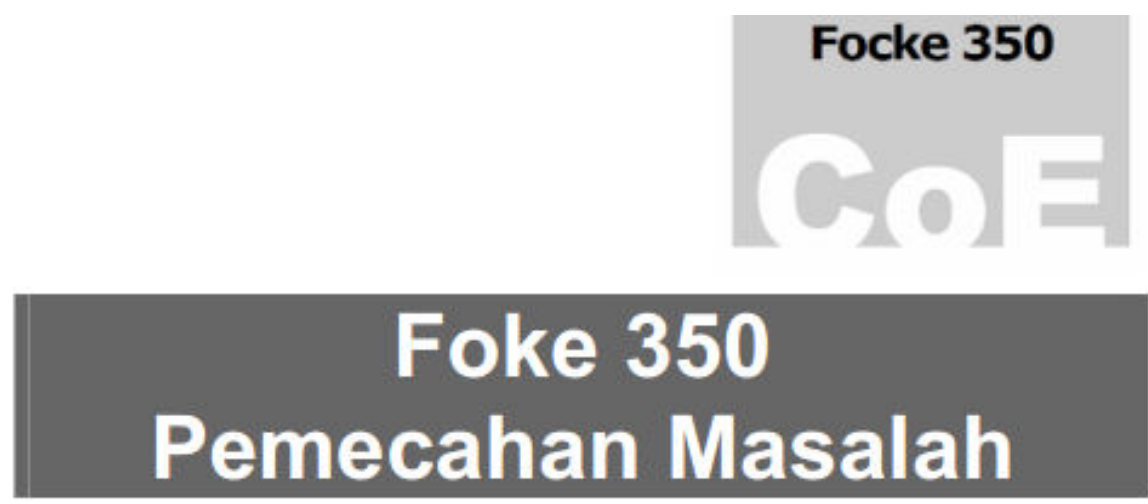

Daftar Isi

\author{
$1 \quad 51.99 .00$ Film: Kusut saat penyegelan \\ $2 \quad 52.40 .02$ Film: Lipatan yang tidak tepat \\ $3 \quad 56.60 .01$ Kertas timah: Kusut / Terlipat \\ 4 54.31. Label(KOTAK/LEMBUT): Miter / Kesejajaran sisi panel (KOTAK)
}

Gambar 2. OPL Perbaikan defect

Sumber : PT. XYZ

Pada Gambar 2 menunjukkan dari pembuatan OPL membantu dalam mempermudah pekerjaan operator dalam melakukan perbaikan terhadap defect yang didapatkan ketika melakukan inspection proses control, OPL juga membantu menyelaraskan masing-masing operator dalam perbaikan sehingga perbaikan langsung pada defect yang terjadi, dalam mencetak OPL untuk di tempatkan pada mesin maka harus mempertimbangkan dari 3 temuan defect yang paling sering terjadi dalam 1 minggu. 


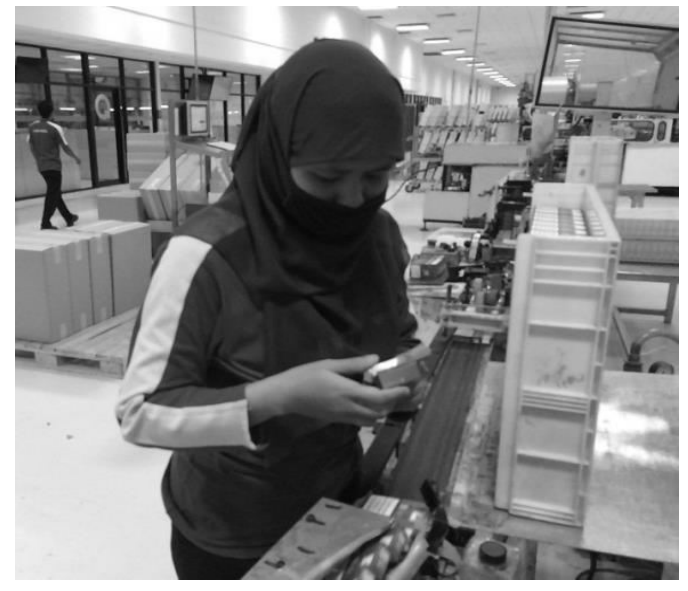

Gambar 3. Penambahan Job- desk IPC Sumber : PT. XYZ

\begin{tabular}{|c|c|c|c|c|c|}
\hline \multicolumn{6}{|l|}{ Packer Focke Line } \\
\hline 7 Dimensi Kerja & No. & $\underline{\mathrm{KPI}}$ & \% & $\frac{\text { Pengukuran }}{\text { Utama }}$ & $\frac{\text { Pengukuran }}{\text { tambahan }}$ \\
\hline Kuantitas Kerja & 1 & Uptime & $10 \%$ & $60 \%$ & $\begin{array}{c}144 \\
\text { box/shift/mesin }\end{array}$ \\
\hline \multirow{2}{*}{ Kualitas Kerja } & 2 & VQI Total & $15 \%$ & 162 point & \\
\hline & 3 & Specific VQI & $15 \%$ & 42 point & \\
\hline \multirow{2}{*}{ Efisiensi Kerja } & 4 & CRR & $10 \%$ & $0.8 \%$ & \\
\hline & 5 & Yield & $5 \%$ & $95.82 \%$ & \\
\hline \multirow{2}{*}{ Otonomi } & 6 & SS & $10 \%$ & $2 \mathrm{SS} /$ year & \\
\hline & 7 & $5 R$ & $5 \%$ & Certified 5R & $1 \mathrm{R}$ per quarter \\
\hline \multirow{2}{*}{ Kontribusi team/Unit } & 8 & NM-HARE & $5 \%$ & $1 \mathrm{card} /$ month & \\
\hline & 9 & $\mathrm{BCC}$ & $5 \%$ & 1 card/quarter & \\
\hline $\begin{array}{l}\text { Belajar keterampilan } \\
\text { dan kemampuan baru }\end{array}$ & 10 & Training & $5 \%$ & $\begin{array}{c}\text { Complete all } \\
\text { planned training }\end{array}$ & \\
\hline $\begin{array}{l}\text { Kepatuhan terhadap } \\
\text { prosedur kerja }\end{array}$ & 11 & Absensi & $5 \%$ & $100 \%$ & \\
\hline Penilaian Tambahan & 12 & Penilaian Personal & $10 \%$ & Based on $7 k$ & rey behavior \\
\hline
\end{tabular}

Gambar 4. Pembobotan penilaian Sumber : Mading Mesin Produksi

Peningkatan awareness/knowledge terhadap kualitas (Quality Ownership) tersebut kemudian di-difusikan atau di-transferkan kepada karyawan, knowledge transfer tersebut diyakini mampu meningkatkan knowledge dan awareness karyawan terhadap pekerjaannya. [5]. Pada gambar 3. maka telah diterapkan penambahan job-desk untuk melakukan IPC pada helper atau support operator untuk melakukan IPC, sehingga semakin banyak orang yang berada pada lini produksi yang sadar akan pentingnya melakukan IPC maka kualitas produk akan semakin terjaga. Gambar 4 menunjukkan lembar pembobotan pengambilan nilai yang dicetak dan ditampilkan di mading mesin sehingga setiap karyawan mengetahui aspek apa sajakah yang dinilai dalam menentukan nilai dari penilaian tahunan. Sehingga jelas untuk menentukan penilaian Feedback Tool for Operation (FTO) menjadi lebih obyektif yaitu antara lain dipengaruhi oleh kuantitas kerja (uptime mesin), kualitas (VQI), effisiensi kerja ditunjukkan dengan jumlah reject rate yang dihasilkan oleh mesin, otonomi adalah keterlibatan karyawan untuk berinovasi dan menjalankan 5R, kontribusi team ditunjukkan oleh blue commitment card dan hazart cart, skill yang ditunjukkan oleh training dilakukan oleh karyawan dan kepatuhan perusahaan diukur dengan menggunakan absensi dari masing-masing karyawan. Setelah melakukan beberapa follow up di atas terhadap root cause untuk melakukan continuous improvement dengan PDCA yang terintegrasi dengan metode A3 Problem Solving maka didapatkan hasil pengamatan nilai VQI pada week 48 sampai dengan week 51, adapun data pengamatan dapat dilihat pada tabel 3 di bawah ini:

Tabel 3. Hasil Pengamatan Nilai VQI Setelah Improvement

\begin{tabular}{|c|c|c|c|c|c|c|c|}
\hline Machine & Component & W48 & W49 & W50 & W51 & W52 & YTD 2016 \\
\hline \multirow[t]{2}{*}{ Machine $\mathrm{X}$} & Cigarete & 155 & 164 & 157 & 158 & & 159 \\
\hline & Pack & 35 & 31 & 32 & 31 & & 32 \\
\hline Total & & 190 & 195 & 189 & 189 & & 191 \\
\hline \multirow[t]{2}{*}{ Machine Y } & Cigarete & 135 & 163 & 161 & 162 & & 155 \\
\hline & Pack & 54 & 32 & 34 & 30 & & 38 \\
\hline Total & & 189 & 195 & 195 & 192 & & 193 \\
\hline \multirow[t]{2}{*}{ Machine $\mathrm{Z}$} & Cigarete & 132 & 147 & 152 & 149 & & 145 \\
\hline & Pack & 60 & 50 & 45 & 45 & & 50 \\
\hline Total & & 192 & 197 & 197 & 194 & & 195 \\
\hline Grand Total & & 190 & 196 & 194 & 192 & & 193 \\
\hline
\end{tabular}


Dari tabel 3 di atas maka dapat dilihat pada nilai dari year to date (YTD) nilai VQI adalah 193 dan secara konsisten nilai VQI tidak pernah lebih dari angka 200.

\section{Kesimpulan}

Penelitian ini mengamati tingkat rasa kepemilikan karyawan terhadap kualitas (Quality ownership) dengan metode A3 Problem Solving yang diintegerasikan dengan metode Continuous Improvement (PDCA) dan juga Failure Mode and Effects Analysis (FMEA) untuk meningkatkan Quality Ownership. Peningkatan Quality Ownership dapat dilihat dari perubahan nilai VQI yang semula diatas 200 dari rata-rata turun menjadi 193 dan konsisten di bawah angka 200, hal tersebut menunjukkan bahwa terjadi pengendalian kualitas dalam proses produksi Adapun saran atau rekomendasi yang diberikan pada penelitian selanjutnya adalah konsep continuous improvement perlu dilakukan sosialisasi dan refreshment kepada seluruh level pekerja dan dukungan penuh dari manajemen, untuk mencapai target yang diharapkan maka perlu melakukan pembobotan ulang untuk kriteria penilaian individu karyawan dengan bobot kualitas kerja (VQI) lebih tinggi dari kuantitas kerja (Uptime) dan konsistensi dalam melakukan inspection proses control (IPC) merupakan kunci dari Quality Ownership sebagai bentuk pengendalian terhadap produk.

\section{Daftar Referensi}

[1] Tan Robiyanto. 2014, Pentingnya Rasa Memiliki (Sense Of Belonging) Dalam Bekerja. HalHttp://Kupasanmanajemenstrategi.Blogspot.Co.Id/2014/03/Pentingnya-Rasa-Memiliki-SenseOf.Html.

[2] Vincent Gasperz. 2001, Manajemen Produktivitas Total. Jakarta: Pt Gramedia Pustaka Utama.

[3] Sujud Triawan. 2004, Peningkatan Kualitas Melalui Penerapan Konsep Kaizen Pada Perusahaan Pengecoran Logam Di Pt. Bakrie Tosanja. Ista Yogyakarta.

[4] Fourry Handoko, Alan Smith and Colin Burvill. 2014, The role of government, universities, and businesses in advancing technology for SMEs' innovativeness. Journal of Chinese Economic and Business Studies, 12:2, 171-180, DOI: 10.1080/14765284.2014.900968

[5] Fourry Handoko, Ellysa Nursanti, Dani Harmanto, dan Sutriyono. 2016, The Role Of Tacit And Codified Knowledge Within Technology Transfer Program On Technology Adaptation. ARPN Journal of Engineering and Applied Sciences, Vol. 11, No. 8, April 2016. 